\title{
MICROSOFT SQL SERVER 2008 - BUSINESS INTELLIGENCE DEVELOPMENT AND MAINTENANCE TRAINING KIT
}

\author{
Iveta ŽOUŽELKOVÁ \\ MICROSOFT SQL SERVER 2008 - VÝVOJ A ÚDRŽBA BUSINESS INTELLIGENCE, \\ TRÉNINGOVÁ SATA
}

(VEERMAN, Erik; LACHEV, Teo; SARKA, Dejan. Microsoft SQL Server 2008 - Business Intelligence Development and Maintenance. Washington : Microsoft Press, 209. 650 s. ISBN 978-07356-2636-2.)

\section{1 Úvod}

Firma Microsoft nabízí celou řadu vzdělávacích programů pro IT specialisty, kteří v praxi používají její nástroje. Tyto kurzy mohou být zakončené zkouškou a úspěšní absolventi získávají certifikaci Microsoft Certification, která je zaměstnavateli celosvětově uznávána a zvyšuje konkurenceschopnost jejího držitele na trhu práce. Microsoft Press $\mathrm{v}$ návaznosti na tyto edukativní programy vydává velmi kvalitní vzdělávací materiál určený nejen zájemcům o již zmíněnou certifikaci, ale i široké odborné veřejnosti. Microsoft SQL Server 2008 Business Intelligence Development and Maintenance Training Kit patří mezi špičkové výukové materiály, které se věnují problematice používání Microsoft SQL Serveru 2008. Ten patří $v$ dnešní době $k$ nejvyhledávanějším nástrojům nejen pro ukládání dat, ale také pro jejich analýzu.

\section{0 autorech}

Autoři knihy se řadí k předním odborníkům v oblasti školení SQL Serveru 2008 a Business Intelligence.

Erik Veerman je ředitelem oddělení Business Intelligence v SolidQ se zaměřením na školení, konzultace a návrhy řešení na platformě SQL Serveru. Během svého profesního života navrhl a realizoval desítky Business Intelligence řešení pro nejrůznější oblasti obchodu a průmyslu, jako jsou naprríklad telekomunikace, marketing, finance, logistika a informační technologie. Kromě své publikační činnosti v odborných časopisech se také věnuje přípravě výukových materiálů. [1]

Teo Lachev patř́ rovněž mezi odborníky na Business Intelligence. Svou 20ti letou praxi zúročuje ve své firmě Prologica, která pomáhá významným organizacím hledat logiku v datech právě za pomocí analytických nástrojů SQL Serveru. [2]
Dejan Sarka rovněž pracuje jako školitel a konzultant ve firmě SolidQ. Mezi jeho aktivity patř́ také publikování odborných knih zaměřených na databázové systémy. [3]

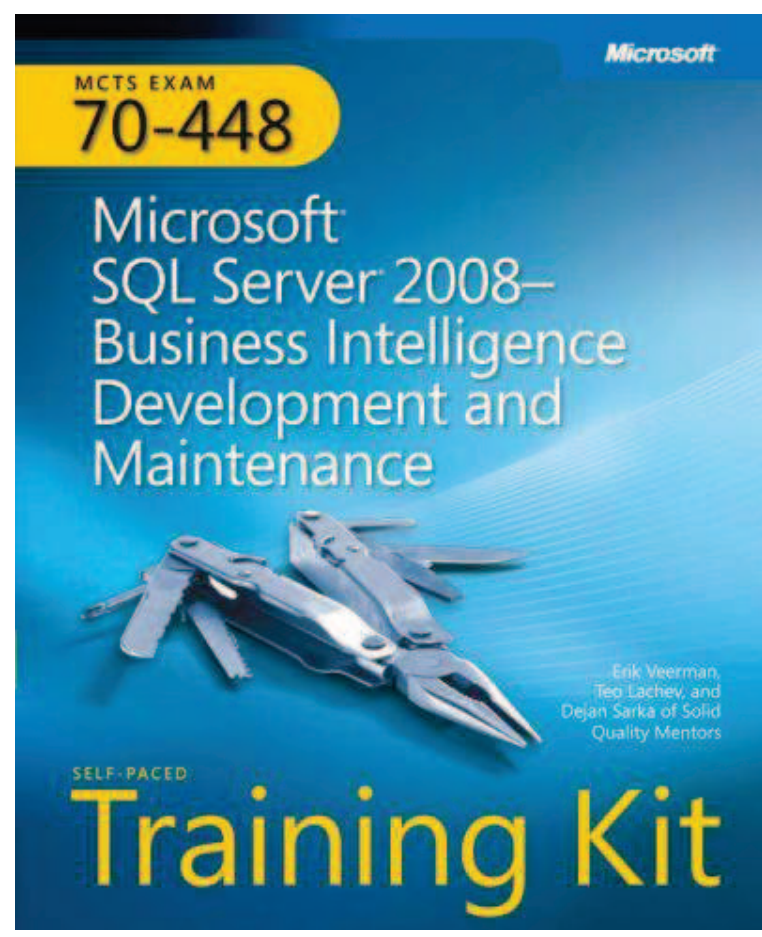

\section{3 Členění a obsah knihy}

Kniha je rozdělena do 13 kapitol, kde každá se věnuje jedné zásadní oblasti nástrojů Business Intelligence. $\mathrm{V}$ úvodu je popsán postup instalace Microsoft SQL Serveru 2008 a jeho analytických nástrojů (Analysis Services). V rámci první kapitoly také nalezneme postup obnovení cvičné databáze AdventureWorks.

Jednotlivé kapitoly obsahují vždy jednu až tři lekce, které na sebe více či méně navazují. Každá kapitola i lekce začíná teoretickým vysvětlením učiva, které by mělo dát čtenáŕi nezbytný znalostní základ k následnému cvičení. To sestává ze série podrobných kroků, které jdou vykonat velmi snadno. Obtížnější části jsou 
doplněny odpovídajícími printsreeny, což usnadní studentovi orientaci V probírané problematice a kontrolu správného postupu.

$\mathrm{Na}$ závěr každé lekce následuje několik kontrolních otázek a správných odpovědí, které čtenáři pomohou zhodnotit míru pochopení probírané problematiky. Výsledky postupů ve cvičeních jsou také průběžně komentovány a vysvětlovány. U jednotlivých lekcí je poznačen předpokládaný čas, který by měl student učivu věnovat. Zkušenost však ukazuje, že deklarovaný čas není dostačující. Většinou je potřeba více než dvojnásobek časového limitu, což může být dáno anglickým jazykem, kterým je kniha napsána.

Kapitola je uzavřena krátkým shrnutím poznatků v bodech a je prripojen prrípadný scénár obdobného případu pro další trénink.

Training Kit je doplněn o výukové materiály na DVD. Kromě celé knihy v elektronické verzi DVD obsahuje také testy ke zkoušce Microsoft Certification, pracovní soubory vztahující se k jednotlivým kapitolám a užitečný slovníček pojmů.

\section{Závěr}

Kniha jistě osloví všechny zájemce o problematiku datových úložišt’ a datovou analýzu. Výukové lekce jsou názorné a velmi přehledné. Jednoduchost a propracovanost kroků uvnitř lekcí zajišt'ují vhodnost knihy i pro úplného začátečníka. Nespornou výhodou je návaznost cvičení uvnitř lekce, ale nezávislost jednotlivých kapitol. Student tak může kteroukoli kapitolu snadno přeskočit a věnovat se pouze tomu, co ho zajímá. Není tedy nutné číst knihu od začátku, což je velkou výhodou pro čtenáře, kteří se potřebují rychle dostat do problematiky, nebo které zajímají jen určité pasáže. Publikace je napsána technickou, ale velmi srozumitelnou angličtinou a je velmi vhodná pro domácí samostudium.

\section{Poděkování}

Článek vznikl za finanční podpory Interní grantové agentury Univerzity Tomáše Bati číslo IGA/FAI/2012/036.

\section{Literatura}

[1] Our Team. SolidQ [online]. 2011 [cit. 201205-15]. Dostupné z: http://www.solidq.com/glen/AboutUS/Pages/description.aspx?name=Erik+ Veerman

[2] Teo Lachev. LinkedIn [online]. 2011 [cit. 2012-05-15]. Dostupné

Z: http://www.linkedin.com/in/tlachev

[3] Our Team. SolidQ [online]. 2011 [cit. 201205-15]. Dostupné z: http://www.solidq.com/glen/AboutUS/Pages/description.aspx?name=Deja $\mathrm{n}+$ Sarka

Ing. Iveta Žouželková

Ústav počítačových a komunikačních systémů

Univerzita Tomáše Bati ve Zlíně

Fakulta aplikované informatiky

nám. T. G. Masaryka 5555,

76001 Zlín,

Česká republika

telefon: +420 576035133

E-mail: zouzelkova@fai.utb.cz, Www pracoviště: www.fai.utb.cz 